\section{Granulozyten, eosinophile}

H. Baum

Institut für Laboratoriumsmedizin, Mikrobiologie und Blutdepot, Regionale Kliniken Holding RKH GmbH, Ludwigsburg, Deutschland

\section{Synonym(e) Eosinophile}

Englischer Begriff eosinophilic granulocyte

Definition Zur myeloischen Zellreihe gehörende Zelle, deren spezifische Granula mit saurem Eosinfarbstoff gefärbt werden kann.

Beschreibung Der eosinophile Granulozyt (s. Abbildung) ist eine reife, im peripheren Blut nachweisbare Zelle der Myelopoese mit einem Durchmesser von ca. 10-15 $\mu \mathrm{m}$ (1000×, May-Grünwald-Giemsa-Färbung):

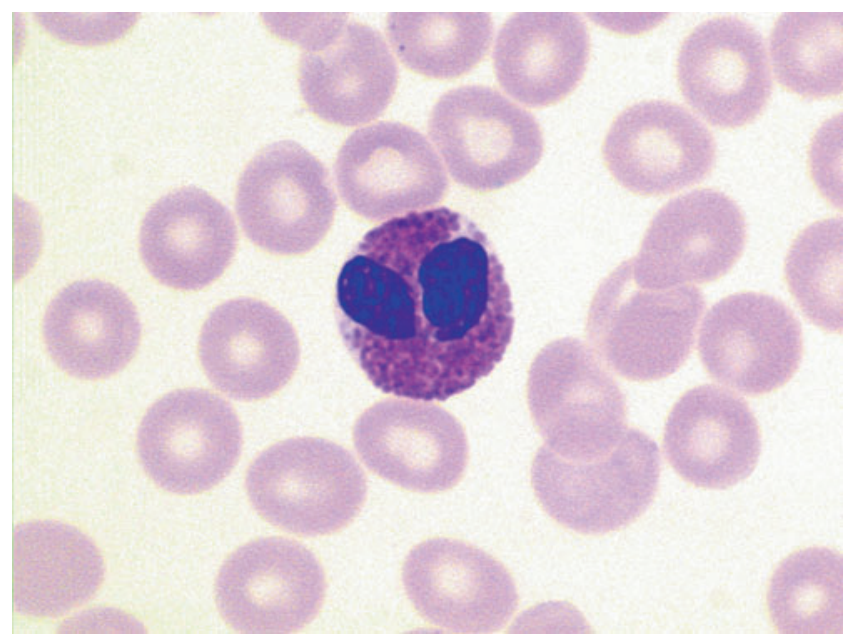

Charakteristisch sind intrazytoplasmatische, sich mit eosinophilen Farbstoffen anfärbende Granula (sekundäre Granula), die praktisch das ganze Zytoplasma ausfüllen. Die Granula fungieren als Lysosomen: Sie enthalten hydrolytische Enzyme und Proteine wie das Major Basic Protein (MBP), > eosinophiles kationisches Protein (ECP). Diese Inhaltsstoffe werden nach Stimulation abgegeben und sind für viele Parasiten, aber auch Gewebe toxisch. Zudem besitzen sie membranständige Proteine, die als Komplement- und IgE-Rezeptoren fungieren. Der Kern der eosinophilen Granulozyten besteht meist aus 2 Kernsegmenten (Zwickelform), das Kernchromatin erscheint dicht. Erhöhungen der eosinophilen Granulozyten im peripheren Blut können in erster Linie bei parasitären und allergischen Erkrankungen nachgewiesen werden. 